\title{
Intraosseous Anesthesia in Hemodynamic Studies in Children with Cardiopathy
}

\author{
Ana Cristina Aliman ${ }^{1}$, Marilde de Albuquerque Piccioni ${ }^{2}$, João Luiz Piccioni, TSA ${ }^{3}$, José Luiz Oliva, TSA ${ }^{3}$, \\ José Otávio Costa Auler Júnior, TSA 4
}

Summary: Aliman AC, Piccioni MA, Piccioni JL, Oliva JL, Auler Júnior JOC - Intraosseous Anesthesia in Hemodynamic Studies in Children with Cardiopathy.

Background and objectives: Intraosseous (IO) access has been used with good results in emergency situations, when venous access is not available for fluids and drugs infusion. The objective of this study was to evaluate $\mathrm{IO}$ a useful technique for anesthesia and fluids infusion during hemodynamic studies and when peripheral intravascular access is unobtainable. The setting was an university hospital hemodynamics unit, and the subjects were twenty one infants with congenital heart disease enrolled for elective hemodynamic study diagnosis.

Methods: This study compared the effectiveness of IO access in relation to IV access for infusion of anesthetics agents (ketamine, midazolam, and fentanyl) and fluids during hemodynamic studies. The anesthetic induction time, procedure duration, anesthesia recovery time, adequate hydration, and IV and IO puncture complications were compared between groups.

Results: The puncture time was significantly smaller in IO group (3.6 min) that in IV group (9.6 min). The anesthetic onset time (56.3 second) for the IV group was faster than IO group (71.3 second). No significant difference between groups were found in relation to hydration (IV group, $315.5 \mathrm{~mL}$ vs IO group, $293.2 \mathrm{~mL}$ ), and anesthesia recovery time (IO group, $65.2 \mathrm{~min}$ vs IV group, $55.0 \mathrm{~min}$ ). The puncture site was reevaluated after 7 and 15 days without signs of infection or other complications.

Conclusions: Results showed superiority for $\mathrm{IO}$ infusion when considering the puncture time of the procedure. Due to its easy manipulation and efficiency, hydration and anesthesia by 10 access was satisfactory for hemodynamic studies without the necessity of other infusion access.

Keywords: Infusions, Intraosseous; Heart Defects, Congenital; Anesthesia; Angiography; Hemodynamics.

[Rev Bras Anestesiol 2011;61(1): 41-49] @Elsevier Editora Ltda.

\section{INTRODUCTION}

Intraosseous (IO) infusion is considered an useful technique for the administration of medications and fluids in emergency situations when peripheral intravascular access is inaccessible and it was used during the World War II. In 1941, Tocantins et al. ${ }^{1}$ introduced the technique for clinical use of fluid infusion that allows immediate access to the vascular system. However, $1 \mathrm{O}$ infusion was gradually substituted by intravenous catheters (1950-1960) ${ }^{2}$. In 1977, from venography studies ${ }^{3}$, the interest in 10 infusion was renewed and recent literature has referred to the use of $1 O$ infusion in emergency situations ${ }^{4,5}$. Since the 10 space has rigid veins that do not collapse in case

Received from the Divisão de Anestesiologia e Terapia Cirúrgica do Instituto do Coração of Hospital das Clínicas of Faculdade de Medicina of Universidade de São Paulo (InCorHC-FM-USP), Brazil.

1. Master's Degree in Anesthesiology from USP, Assistant Physician at InCor-HC-FM-USP. 2. PhD in Anesthesiology from USP. Assistant Physician at Anesthesiology Service of InCorHC-FM-USP.

3. Anesthesiologist, Certified by Sociedade Brasileira de Anestesiologia. Assistant Physician at Anesthesiology Service of InCor-HC-FM-USP.

4. Anesthesiologist, Certified by Sociedade Brasileira de Anestesiologia. Professor at Anes-

thesiology Discipline - Surgery Service, FM-USP.

Submitted on July 28, 2010

Approved on August 12, 2010.

Correspondence to:

Dr. José Otávio Costa Auler Júnior

Av. Dr. Enéas de Carvalho Aguiar, $44-2^{\circ}$ andar - bloco I

Cerqueira César

05403-000 - São Paulo, SP, Brazil

E-mail: auler.junior@incor.usp.br of hypovolemia or systemic circulatory failure, it has been considered as an alternative in emergency situations when venous access is extremely difficult. The 10 technique is included in standard protocols and training procedures such as the Advanced Pediatric Life Support textbook ${ }^{6}$ and it is recommended by the American Heart Association ${ }^{7}$ and the American Academy of Pediatrics ${ }^{8}$.

Infants with congenital heart disease when undergoing to hemodynamic studies need general anesthesia and they are mainly underweight infants whose venous access is very difficult. The aim of this study was to demonstrate the feasibility of $\mathrm{IO}$ access and its efficiency for administering anesthetics agents and hydration fluids during hemodynamic studies to infants with congenital cardiopathies and difficult venous access by conventional means.

\section{METHODS}

After the Institutional Ethics Committee approval and parental consent, infants aged 1 to 12 months with congenital cardiac diseases scheduled for elective hemodynamic study and requiring general anesthesia without tracheal intubation were included. ASA physical statuses were III or IV. None of the infants had fever, cough, viral infection, diarrhea or vomits. For $1 \mathrm{O}$ infusion technique, patients that had any localized infection were excluded from the study. 


\section{PROTOCOL}

The first step in the preparation of infants eligible for the hemodynamic study was to inform the parents about the risks associated with anesthesia and about the hemodynamic study. In addition, the parents were informed that the infant should not drink any water 3 hours and no milk 4 hours before surgery ${ }^{9}$. Premedication was intramuscular (IM) ketamine ${ }^{10} 1 \mathrm{mg} \mathrm{kg}^{-1}$ for either venous access or intraosseous technique. Infants were separated into Intravenous group (IV) and Intraosseous group (IO). Groups IV and IO consisted of 10 and 11 infants respectively. In the 10 group the venous access was extremely difficult and would be obtained only by profound venous puncture or dissection. The IO technique was preceded by rigorous asepsis and local anesthesia (lidocaine 1\% without epinephrine) followed by the insertion of a $30 \times 0,9 \mathrm{~mm}$ sterile needle in the tibia, connecting a continuous infusion pump for the administration of anesthetic agents and fluids. After local anesthesia, an 10 puncture was performed 1 to $2 \mathrm{~cm}$ just below the tibial tuberosity. Needle should be held in a $45^{\circ}$ to $60^{\circ}$ inclination and introduced with gentle circular movements until slight resistance was overcome following a short cracking sound. There should be continuous aspiration with a $3 \mathrm{~mL}$ syringe containing $2 \mathrm{~mL}$ of distilled water, which should make it easier to view the brown substance when aspired. When the infant started to wake up, it was time to inject the following anesthetics: IV group received midazolam $0.20 \mathrm{mg} \mathrm{kg}^{-1}$, fentanyl $2.24 \mu \mathrm{g} \mathrm{kg}^{-1}$, and ketamine $2.24 \mathrm{mg} \mathrm{kg}^{-1}$; and IO group received midazolam $0.28 \mathrm{mg} \cdot \mathrm{kg}^{-1}$, fentanyl $4.7 \mu \mathrm{g} \cdot \mathrm{kg}^{-1}$, and ketamine $4.7 \mathrm{mg} \cdot \mathrm{kg}^{-1}$. The anesthetics agents were repeated in bolus when necessary for maintenance of anesthesia. The IO procedure was confirmed by radioscopy after injecting contrast $\left(\right.$ Hexabrix ${ }^{\circledR}$ ) (Figure 1). After the infant was anesthetized, the needle set was protected with gauze and plaster forming a cushion, connecting the infusion pump (Infusion Pump 670-SAMTRONIC) for the administration of drugs and fluids (Figure 2). This technique was kept as a venous access for maintenance of anesthesia during hemodynamic study until infant recovered completely from anesthesia and the infusion was interrupted only after complete hydration of the infant. The hydration was accomplished with a mixed solution of glucose $5 \%(50 \mathrm{~mL})$ and saline $0.9 \%(50 \mathrm{~mL})$ on the dose of $20 \mathrm{~mL} \cdot \mathrm{kg}^{-1} \cdot \mathrm{h}^{-1}$. The puncture spot was reevaluated after 7 and 15 days (Figure 2). The infants were clinically evaluated by a pediatrician after one week, six months and one year and no complications regarding the techniques applied on this study were reported.

All results were reported as mean \pm standard deviation. After inspecting for normality and homogeneity of variance among groups, differences between groups were calculated using the unpaired Student's $t$ test. Analysis included Wilcoxon's test when appropriate. Statistical analysis was performed using PadGraph Prism software (GraphPad Software Inc., San Diego, CA, U.S.A.).

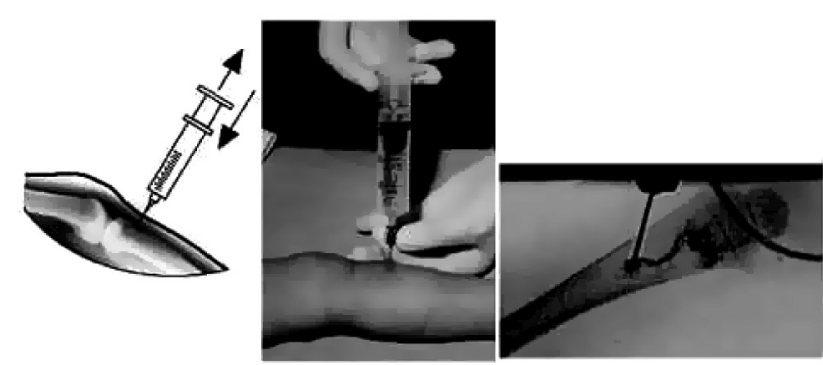

Figure 1 - The Intraosseous Technique and Infusion of Anesthetic Agents.

Left, middle: The intraosseous technique for infusion of anesthetic agents. Right: radioscopy after injecting contrast (Hexabrix®) confirmed the needle's position.
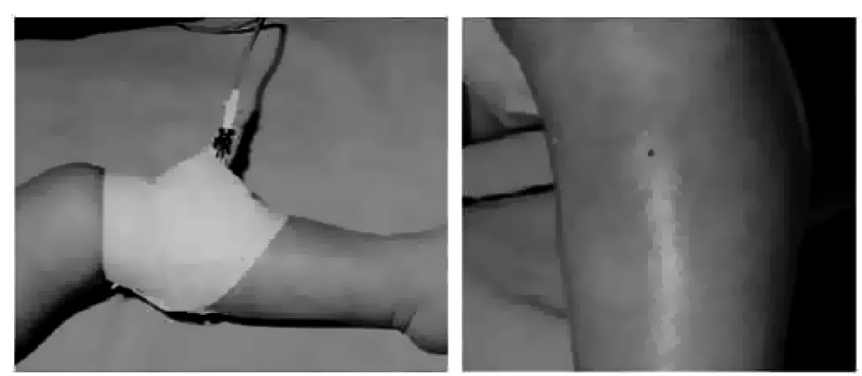

Figure 2 - Connecting the Infusion Pump.

Left: Infusion pump line connected to administer medications and fluids. Right: Intraosseous puncture spot.

\section{RESULTS}

Table I summarizes etiologic aspects of congenital heart diseases enrolled in the study. The main age of infants was $7.9 \pm 4.3$ months (IV group) and $7.8 \pm 3.8$ months (IO group), mean weight was $7.2 \pm 1.3 \mathrm{~kg}$ (IV group) and $6.9 \pm 1.9 \mathrm{~kg}$ (IO group), six were female and four were male (IV group) and in the IO group four infants were female and seven were male. Table II summarizes the results of the technique of puncture in the IV group and IO group. The only significant difference for the technique between groups was the puncture time $(p=$ 0.012 ). The mean anesthetic dose used in the IV group were midazolam $\left(1.58 \pm 0.03 \mathrm{mg} \cdot \mathrm{kg}^{-1}\right)$, ketamine $(17.64 \pm 0.25$ mg.kg-1), and fentanyl $\left(17.64 \pm 0.25 \mathrm{mg}^{-1} \mathrm{~kg}^{-1}\right)$. In the $\mathrm{IO}$ group those were midazolam $\left(2.18 \pm 0.08 \mathrm{mg}^{\mathrm{kg}}{ }^{-1}\right)$, ketamine $(36.6 \pm$ $\left.0.80 \mathrm{mg}^{\mathrm{kg}}{ }^{-1}\right)$, and fentanyl $\left(36.6 \pm 0.80 \mathrm{mg}^{\mathrm{kg}}{ }^{-1}\right)$ (Figure 3$)$. The onset time of anesthesia ( 56.3 second) in the IV group was faster than in IO group (71.3 second) $(p=0.014)$ (Figure 4). The hydration was $20 \mathrm{~mL} \cdot \mathrm{kg}^{-1} \cdot \mathrm{h}^{-1}$ with the solution described and no significant differences between groups: IV group $(315.5 \pm 15.5$ $\mathrm{mL})$, IO group $(293.2 \pm 67.4 \mathrm{~mL})(\mathrm{p}=0.320)$. The time for anesthesia recovery in IO group $(65.2 \pm 20.9 \mathrm{~min})$ and IV group (55.0 $\pm 14.0 \mathrm{~min}$ ) were not different $(p=0.201)$ (Figure 4). 
Table I - Etiologic Aspects of Congenital Heart Diseases of Peripheral Intravenous Infusion Group or Anesthesia Intraosseous Infusion Group

\begin{tabular}{lll}
\hline & IV group & IO group \\
\hline Truncus arteriosus & 1 & - \\
Tricuspid atresia & 2 & 1 \\
Tetralogy of Fallot & 4 & 3 \\
Tetralogy of Fallot with pulmonary atresia & - & 1 \\
Tetralogy of Fallot with stenosis pulmonary valve & - & 1 \\
Common ventricle & 2 & - \\
Transposition of the great arteries & 1 & - \\
Coarctation of aorta with Aortic stenosis & - & 1 \\
Total anomalus pulmonary venous drainage & - & 2 \\
Ventricular septal defect with pulmonary & - & 1 \\
hypertension & - & 1 \\
Situs inversus & - & \\
\hline
\end{tabular}

IV group: Intravenous group; IO group: Intraosseous group.

\section{DISCUSSION}

This study has contemplated two different techniques for the infusion of anesthetics agents and hydration during hemodynamic studies in patients with congenital cardiopathies and difficult venous access by conventional means. Our main interest was to demonstrate the efficiency of the 10 technique for anesthesia and hydration in the hemodynamic unit. The results demonstrate that $\mathrm{IO}$ infusion was an effective method to access the vascular system and delivery to the central circulation, and could be an alternative method for unreachable peripheral venous access. The time to insert the IV needle varied from 4 minutes to 11.5 minutes, with a mean of 9.6 minutes, related to the practitioner's skills. The time to place the IO needle varied from 2 minute to 5 minutes, with a mean of 3.6 minutes, with a significant difference between the groups. The technique of venous cutdown is part of the training program of Advanced Pediatric Life Support. The most preferred cutdown

Table II - Technique of Puncture in the Intravenous Group and Intraosseous Group

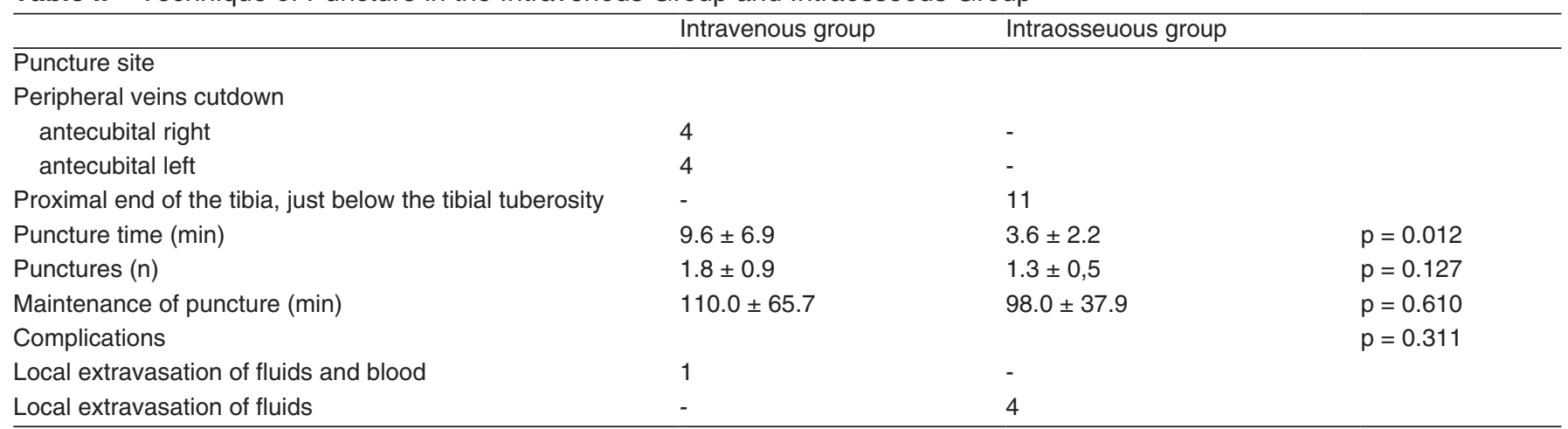

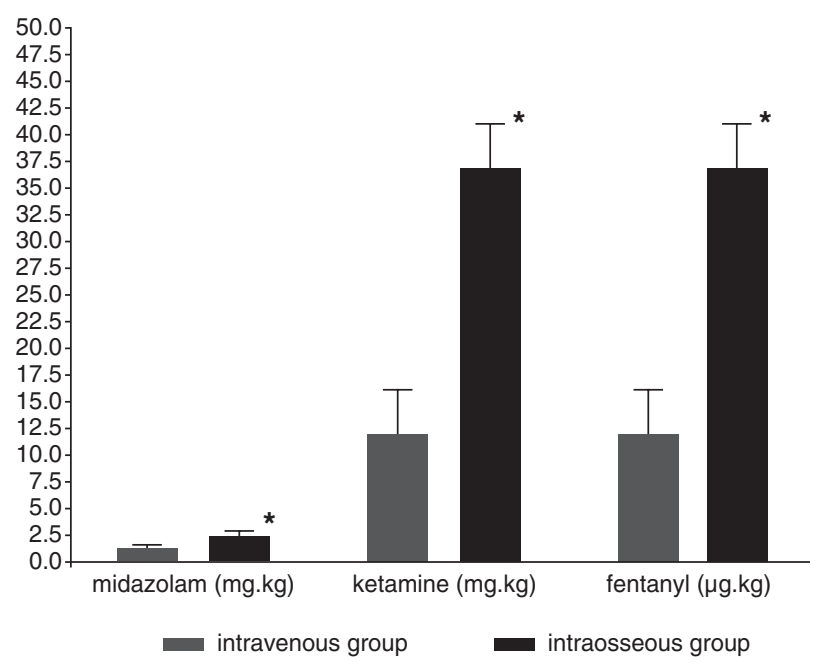

Figure 3 - Anesthetic Agentes used during Hemodynamic Study. Higher dose of anesthesic agents was observed: midazolam ( $p=$ $0.007)$, ketamine $(p<0.001)$ and fentany $(p<0.001)$ in the intraosseous group when compared with the intravenous group.

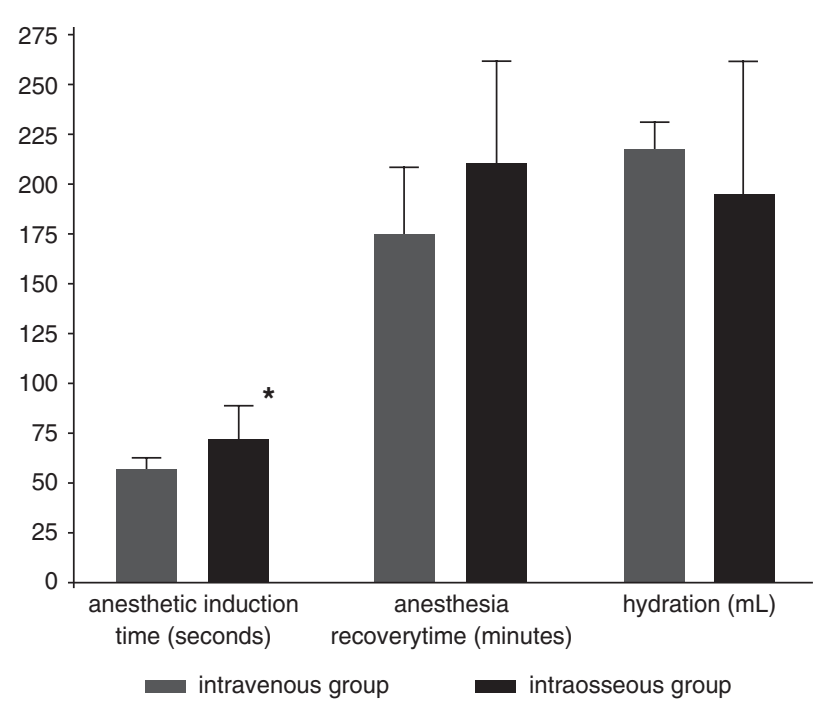

Figure 4 - Time of Anesthetic Induction and Anesthesia Recovery Time, Hydration Volume.

The induction time was faster for the IV group ( $\left.{ }^{*} p=0.0145\right)$. 
access site is the saphenous vein above the medial malleolus of the tibia, but antecubital, axillary, cephalic and femoral vessels are also suitable and improved procedures using Seldinger techniques have been reported ${ }^{11,12}$. The usual time to achieve access by pediatric surgeons was $6 \mathrm{~min}$ in children aged 6-16 years, 8 min in those aged 1 month to 5 years, and $11 \mathrm{~min}$ in neonates ${ }^{13}$. This time delay makes its use unrealistic for most clinicians, and 10 or percutaneous femoral access can be achieved more rapidly ${ }^{11}$.

The IO method was compared to the peripheral IV method using the following anesthetic agents: midazolan, ketamine, fenatyl. The effectiveness of hydration on $1 \mathrm{O}$ route has also been tested, demonstrating that this method could be an alternative when peripheral access is considered difficult or impossible (Figures 1 and 3). This study demonstrated a quick systemic flow during $1 \mathrm{O}$ infusion (Figure 2). The case reported and reviewed literature 15 of severe laryngospasm during inhalation induction of pediatric patients without intravenous accesss. The speed and effectiveness in treating laryngospasm by intravenous route with suxamethonium agent used as a muscle relaxant was achieved when other IV routes had been inaccessible. Despite intramuscular route being easier, the time response was much slower than the intraosseos route. Clinical experience indicates that the IO route is probably superior to the intramuscular route, and comparable to the intravenous route in response time.

Helm et al. ${ }^{15}$ demonstrated the other alternative to the puncture of peripheral veins in emergency situations with children less than 6 years of age. In $37 \%$ of the cases (10/27) the 10 infusion line was used for induction of general anesthesia; dosage and onset of administered drugs were described as being equivalent to a peripheral infusion line. In all cases, the IO needle was replaced in-hospital within $2 \mathrm{~h}$ by a central or peripheral IV line. No complications were observed, and the IO infusion technique was considered a simple, fast and safe alternative method for emergency access to the vascular system in children less than 6 years of age in the pre-hospital setting.

In another study it was observed that the greatest advantage of 10 route is the high success rate (about $80 \%$ ) and most experienced providers can reach an IO route within 1 to 2 minutes. A number of smaller studies and case studies have established the usefulness of this route for the delivery of all resuscitation drugs. the most common side effect seen when using 10 route is extravasation. It has been reported in $12 \%$ of patients. Compartment syndrome, osteomyelitis, and tibial fracture are rare, but have been reported as well. The side effect of 10 method was extravasation on 4 children that had a good recovery (Table II).

IO access can be used as an alternative line for medication/ volume expansion when umbilical or other direct venous access are not readily attainable (Class IIb, LOE 5) ${ }^{17}$. Two prospective randomized trials in adults and children (LOE 3) ${ }^{18,19}$ and 6 other studies (LOE 4 20; LOE $5^{21,22 ; ~ L O E ~} 7^{23,24}$ ) have supported $\mathrm{IO}$ access as safe and effective for fluid resuscitation, drug delivery, and blood sampling for laboratory evaluation. The consensus process (2006) that produced this document was sponsored by the International Liaison Committee on Resuscitation (ILCOR) and demonstrated per patient IO success rates that were high despite a small number of attempts over a prolonged time period. These data suggest that successful IO access with a low complication rate can be accomplished despite its infrequent use.

In our study, it was observed that after having administrated anesthetics agents the onset time for IO infusion was significantly faster than the observed in the IV group however the mean mass of anesthetic agents were smaller for IV group. Nevertheless, even though the higher anesthetics dose for 10 group impaired anesthesia recovery time, no difference was observed between the groups for awakenings. The time for the cathether maintenance was similar in the groups. The fasting before procedure and the injection of hyperosmolar contrast were factors that may contribute to cause important dehydration during hemodynamic studies, therefore it is necessary to promote the infusion of fluids during this procedure. The volume of fluid for hydration was similar in both groups, but in the 10 group an infusion pump for administering fluids was necessary because the high vascular 10 resistance. Considering that since the 1830s fluids have been administered intravenously, and IV access is not always possible to be established, the 10 route provides rapid, safe and easy access to the vascular system.

In conclusion when peripheral IV access is unobtainable, $\mathrm{IO}$ infusion has been shown to be an effective and safe alternative for administering anesthetic agents and fluids for hemodynamic studies. 


\section{REFERÊNCIAS / REFERENCES}

01. Tocantins LM, O'Neill JF, Jones HW - Infusions of blood and other fluids via the bone marrow; applications in pediatrics. JAMA, 1941;117:1229-1234.

02. Cournand $\mathrm{J}-$ Technique for insertion of plastic catheter into saphenous vein. Pediatrics, 1941;24:631-637.

03. Begg AC - Intraosseous venography of the lower limb and pelvis. $\mathrm{Br}$ J Radiol, 1954;27:318-324.

04. Engle WA - Intraosseous access for administration of medications in neonates. Clin Perinatol, 2006;33:161-168.

05. Smith R, Davis N, Bouamra O et al. - The utilisation of intraosseous infusion in the resuscitation of paediatric major trauma patients. Injury, 2005;36:1034-1038.

06. Mackway-Jones KME, Phillips B, Wieteska S. - Intraosseous 
transfusion, em: Mackway-Jones KME, Molyneix E, Phillips B et al - Advanced Paediatric Life Support. $3^{\text {rd }}$ Ed, London, BMJ Books, 2001;229-230.

07. American Heart Association - 2005 American Heart Association guidelines for cardiopulmonary resuscitation and emergency cardiovascular care. International consensus on science. Circulation, 2005;112:iv12-iv211.

08. Brown K, Lightfoot C - The 2005 Guidelines for CPR and Emergency Cardiovascular Care: Implications for Emergency Medical Services for Children. Clin Ped Emerg Med, 2006;7:105-113.

09. Goresky GV, Maltby JR - Fasting guidelines for elective surgical patients. Can J Anaesth, 1990;37:493-495.

10. Green SM, Johnson NE - Ketamine sedation for pediatric procedures: Part 2 - Review and implications. Ann Emerg Med, 1990;19:10331046.

11. Haas NA - Clinical review: vascular access for fluid infusion in children. Crit Care, 2004;8:478-484.

12. Iserson KV, Criss EA - Pediatric venous cutdowns: utility in emergency situations. Pediatr Emerg Care, 1986;2:231-234.

13. Westfall MD, Price KR, Lambert $\mathrm{M}$ et al. - Intravenous access in the critically ill trauma patient: a multicentered, prospective, randomized trial of saphenous cutdown and percutaneous femoral access. Ann Emerg Med, 1994;23:541-545.

14. Seah TG, Chin NM - Severe laryngospasm without intravenous access--a case report and literature review of the non-intravenous routes of administration of suxamethonium. Singapore Med J, 1998;39:328-330.

15. Helm M, Hauke J, Bippus $\mathrm{N}$ et al. - Die intraossare Punktion in der praklinischen Notfallmedizin. 10-jahrige Erfahrungen im Luftrettungsdienst. Anaesthesist, 2007;56:18-24.

16. Buck ML, Wiggins BS, Sesler JM - Intraosseous drug administration in children and adults during cardiopulmonary resuscitation. Ann Pharmacother, 2007;41:1679-1686.

17. Banerjee $S$, Singhi SC, Singh $S$ et al. - The intraosseous route is a suitable alternative to intravenous route for fluid resuscitation in severely dehydrated children. Indian Pediatr, 1994;31:1511-1520.

18. Brickman KR, Krupp K, Rega P et al. - Typing and screening of blood from intraosseous access. Ann Emerg Med, 1992;21:414-417.

19. Fiser RT, Walker WM, Seibert JJ et al. - Tibial length following intraosseous infusion: a prospective, radiographic analysis. Pediatr Emerg Care, 1997;13:186-188.

20. Ummenhofer W, Frei FJ, Urwyler A et al. - Are laboratory values in bone marrow aspirate predictable for venous blood in paediatric patients? Resuscitation, 1994;27:123 -128.

21. Guy J, Haley K, Zuspan SJ - Use of intraosseous infusion in the pediatric trauma patient. J Pediatr Surg, 1993;28:158-161.

22. Macnab A, Christenson J, Findlay J et al. - A new system for sternal intraosseous infusion in adults. Prehosp Emerg Care. 2000;4:173 -177.

23. Ellemunter H, Simma B, Trawoger R et al. - Intraosseous lines in preterm and full term neonates. Arch Dis Child Fetal Neonatal Ed, 1999;80:F74 -F75.
24. International Liaison Committee on Resuscitation - The International Liaison Committee on Resuscitation (ILCOR) consensus on science with treatment recommendations for pediatric and neonatal patients: pediatric basic and advanced life support. Pediatrics, 2006;117(5):e955-977.

Resumen: Aliman AC, Piccioni MA, Piccioni JL, Oliva JL, Auler Junior JOC - Anestesia Intraosea en Estudio Hemodinamico en Nino Cardiopata.

Justificativa y objetivos: El acceso intraoseo (IO), se ha venido utilizando con buenos resultados en situaciones de emergencia, cuando no existe el acceso venoso disponible para la administracion de fluidos y farmacos. El objetivo del presente estudio es evaluar si el acceso IO es una tecnica util para la administracion de anestesia y de fluidos en el estudio hemodinamico cuando el acceso periferico es imposible de obtenerse. Ese estudio fue realizado en el laboratorio de hemodinamica de un hospital universitario, con 21 lactantes portadores de enfermedad cardiaca congenita que fueron seleccionados para un estudio hemodinamico diagnostico.

Métodos: Este estudio comparo la efectividad del acceso IO con relacion al EV para la infusion de anestesicos (quetamina, midazolam y fentanil), y de fluidos durante el estudio hemodinamico. El tiempo de induccion anestesica, la duracion del procedimiento, el tiempo de recuperacion de la anestesia, la adecuada hidratacion y las complicaciones de las punciones EV e IO se compararon entre los grupos.

Resultados: El tiempo de puncion fue significativamente menor en el grupo IO (3,6 minutos) que en el grupo EV (9,6 minutos). El tiempo de inicio de la accion de la anestesia fue mas rapido en el grupo EV (56,3 segundos) que en el grupo IO (71,3 segundos). No se observaron diferencias significativas entre los dos grupos con relacion a la hidratacion (grupo EV $315,5 \mathrm{~mL}$ vs. grupo IO 293,2 mL), y sobre el tiempo de recuperacion de la anestesia (grupo IO 65,2 min vs, grupo EV $55,0 \mathrm{~min}$ ). El sitio de la puncion se evaluo nuevamente despues de 7 a 15 dias, y no presento senales de infeccion u otras complicaciones.

Conclusiones: Los resultados comparativos arrojaron una superioridad de la infusion IO con relacion al tiempo de puncion. Debido a su eficiencia y manipulacion bastante facil, la hidratacion y la anestesia que se hicieron por medio de la infusion 10 demostraron ser satisfactorias para los estudios hemodinamicos sin la necesidad de otros accesos.

Descriptores: ANESTESIA; ENFERMIDAD: Cardiaca, Congenita; TÉCNICAS ANESTÉSICAS, General: venosa; TÉCNICAS DE MEDICIÓN, Hemodinâmica. 